\title{
KEBIJAKAN INTERVENSI PENANGANAN STUNTING TERINTEGRASI
}

\author{
Dahlan Tampubolon \\ Pusat Studi Sosial Ekonomi LPPM Universitas Riau Pekanbaru
}

\begin{abstract}
The purpose of this study evaluates the stunting intervention policy in Riau Province in 2018 and 2019. The object of study is the Government of Rokan Hulu Regency, Kampar Regency and Riau Provincial Government, especially the Regional Development Planning Agency and the Health Office. Field observations and interviews in two villages in Rokan Hulu Regency and one village in Kampar Regency included in the stunting locus according to Riskesdas. The method used is a mixed method with a minimum analysis that is quantitative-descriptive analysis supported by qualitative analysis obtained from in-depth interviews, field observations and FGDs. The government in a structured manner starting from the central and regional governments has made various interventions towards stunting. Local governments have not included stunting as an indicator of health performance outcomes. The Health Department has worked on several programs and activities related to stunting interventions. Performance targets for health service performance have been included in performance agreements and reported in the Government Institution Performance Report (LKjIP) of the Kampar District Government. The central government has budgeted special transfer funds through the 2018 Special Allocation Fund (DAK) and 2019 DAK. The Riau Provincial Government has only accommodated the handling of stunting in the 20142019 RPJMD revision planning document. Stunting interventions in Riau Province have been carried out through specific and sensitive intervention strategies. Specific interventions are mostly in the programs and activities of the Health office, both the Health Office. Coordination at the provincial level has not been found for cross-sectoral coordination so that the existing programs and activities run each with a different target.
\end{abstract}

\begin{abstract}
Abstrak: Tujuan studi ini mengevaluasi kebijakan intervensi stunting di Provinsi Riau tahun 2018 dan 2019. Objek kajian adalah Pemerintah Kabupaten Rokan Hulu, Kabupaten Kampar dan Pemerintah Provinsi Riau, terutama Badan Perencanaan Pembangunan Daerah dan Dinas Kesehatan. Observasi lapangan dan wawancara di dua desa di Kabupaten Rokan Hulu dan satu desa di Kabupaten Kampar yang masuk dalam lokus stunting menurut Riskesdas. Metode yang digunakan berupa mixed method dengan analisis minimum yaitu analisis kuantitatif-deskriptif yang didukung analisis kualitatif yang diperoleh dari wawancara mendalam, observasi lapangan dan FGD. Pemerintah secara terstruktur mulai dari pemerintah pusat dan daerah telah melakukan berbagai upaya intervensi terhadap stunting. Pemerintah Daerah belum memasukkan stunting sebagai indikator capaian kinerja kesehatan. Dinas Kesehatan telah mengerjakan beberapa program dan kegiatan yang berkaitan dengan intervensi stunting. Target pencapaian kinerja dinas kesehatan telah dimuat dalam perjanjian kinerja dan dilaporkan dalam Laporan Kinerja Instansi Pemerintah (LKjIP) Pemerintah Kabupaten Kampar. Pemerintah pusat telah menganggarkan dana transfer khusus melalui Dana Alokasi Khusus (DAK) 2018 dan DAK 2019. Pemerintah Provinsi Riau baru mengakomodir penanganan stunting dalam dokumen perencanaan revisi RPJMD Tahun 20142019. Intervensi stunting Provinsi Riau telah dilakukan baik melalui strategi intervensi spesifik maupun sensitif. Koordinasi di level Provinsi belum ditemukan adanya koordinasi lintas sektor sehingga program dan kegiatan yang ada berjalan masing-masing dengan sasaran yang berbeda.
\end{abstract}

Kata kunci: kebijakan, intervensi stunting, capaian kinerja, dan perjanjian kinerja.

\section{PENDAHULUAN}

Perhatian global terhadap gizi kurang sangat besar saat ini. Hal itu untuk meningkatkan kesejahteraan miliaran orang, dengan konsekuensi positif bagi kesehatan, perkembangan, sekolah, dan penghasilan mereka (Leroy \& Frongillo, 2019). Ada sekitar 160 juta anak di bawah usia 5 tahun dan tinggal di negara berkembang sangat kekurangan gizi (de Onis \& Branca, 2016).
Kekurangan gizi kronis pada kehidupan awal akan merugikan masa depan, termasuk kurang pendidikan, keterampilan kognitif yang lebih buruk, pendapatan yang lebih rendah dan lebih tinggi kemungkinannya hidup dalam kemiskinan (Hoddinott, Rosegrant, \& Torero, 2013).

Konsekuensi dari anak stunting bersifat jangka panjang termasuk peningkatan morbiditas dan mortalitas, perkembangan anak yang buruk 
dan kapasitas belajar, rentan infeksi dan penyakit tidak menular di masa dewasa, dan berkurangnya produktivitas dan kemampuan ekonomi (Stewart, Iannotti, Dewey, Michaelsen, \& Onyango, 2013). Persoalan lainnya, secara ekonomi akan menghambat pertumbuhan ekonomi dan produktivitas pasar kerja. Hilangnya sekitar 11 persen dari PDB dan mengurangi pendapatan pekerja dewasa hingga 20 persen. Selanjutnya akan memperparah ketimpangan (inequality) dan mengurangi 10 persen dari total pendapatan seumur hidup, akibatnya memperparah kemiskinan antar-generasi. Di masa mendatang akan menghambat pembangunan dan peluang menjadi negara maju.

Menurut Riset Kesehatan Dasar(Riskesdas) mengenai balita pendek di Indonesia pada tahun 2013 adalah (37,2 persen), jika dibandingkan pada tahun 2010 (35,6 persen) dan tahun 2007 (36,8 persen) tidak menunjukan penurunan/ perbaikan yang signifikan (Kementerian Kesehatan, 2013). Persentase tertinggi pada tahun 2013 adalahProvinsi Nusa Tenggara Timur (51,7 persen), Sulawesi Barat (48,0 persen), dan Nusa Tenggara Barat (45,3 persen), sedangkan persentase terendah adalah Provinsi Kepulauan Riau (26,3 persen), DI Yogyakarta (27,2 persen) dan DKI Jakarta (27,5 persen) (Kementerian Kesehatan, 2016).

Banyak kajian di Indonesia telah membahas faktor penentu kesehatan dan perawatan kesehatan. Antara lain, akses yang tidak memadai ke perawatan kesehatan dikaitkan dengan anak stunting (Anwar, Khomsan, Riyadi, \& Mudjajanto, 2010), (Bardosono, Sastroamidjojo, \& Lukito, 2007), dan (Torlesse, Cronin, Sebayang, \& Nandy, 2016). Anak-anak yang memiliki risiko kematian tinggi, seringkali dapat dengan cepat diatasi dengan terapi nutrisi (Bhutta, et al., 2017). Sebaliknya, anak-anak yang dikategorikan terhambat pertumbuhan tinggi badannya, tidak dapat menerima koreksi nutrisi karena dianggap memerlukan pencegahan daripada pengobatan (Bergeron \& Castleman, 2012). Perlu intervensi program dan pembiayaan mengatasi kekurangan gizi akut dan kronis sebagai program yang berbeda oleh para pembuat kebijakan (Development Initiatives, 2018).
Dalam Riskesdas 2013 jumlah stunting mencapai 9 juta anak (37,2 persen) dan pada Sirkesnas 2016 menjadi 33,6 persen. Di Riau, berdasarkan Riskesdas 2013, Kabupaten Rokan Hulu menjadi daerah tertinggi dengan prevalensi stunting mencapai 58,9 persen dan menurun menjadi 27,3 persen pada tahun 2018 (Kementerian Kesehatan, 2018). Penurunan ini salah satunya dicapai dari hasil upaya Kementerian Kesehatan Republik Indonesia melalui pelaksanaan percepatan penurunan stunting. Kabupaten Kampar pada Riskesdas 2013 memiliki prevalensi stunting mencapai 32,1 persen dan setelah lima tahun tidak ada perbaikan atas prevalensinya, tetap 32,1 persen.

Implementasi kebijakan intervensi stunting di Provinsi Riau dimulai di Kabupaten Rokan Hulu pada tahun 2018 dan kebijakan intervensi di Kabupaten Kampar dimulai pada tahun 2019. Implementasi tersebut menjadi fokus evaluasi kebijakan. Pelaksanaan intervensi stunting di dua kabupaten tersebut perlu ditelaah dan dievaluasi berdasarkan permasalahan-permasalahan yang terdapat di lapangan terkait penerapan kebijakan intervensi stunting.

\section{METODE}

Objek kajian adalah Pemerintah Kabupaten Rokan Hulu, Kabupaten Kampar dan Pemerintah Provinsi Riau, terutama Badan Perencanaan Pembangunan Daerah dan Dinas Kesehatan. Kedua Organisasi Perangkat Daerah (OPD) ini terlibat langsung sejak perencanaan dan pelaksanaan kebijakan intervensi penanganan stunting. Observasi lapangan dan wawancara juga dilakukan pada 2 (dua) desa di Kabupaten Rokan Hulu dan 1 (satu) desa di Kabupaten Kampar yang masuk dalam lokus stunting menurut Riskesdas.

Metodologi di dalam evaluasi Intervensi Penanganan Stunting Terintegrasi Di Riau menggunakan metode kualitatif. Penggunaan indikator Dunn untuk mengevaluasi kebijakan publik dibutuhkan untuk mengukur keberhasilan program dan kebijakan publik (Dunn, 2017). Metode ini memanfaatkan data kuantitaif untuk menggali informasi lebih dalam yang bersifat kualitatif yang diperoleh melalui wawancara dan observasi, serta diskusi kelompok terarah. Metodologi 
yang digunakan berupa mixed method dengan analisis minimum, yaitu analisis kuantitatifdeskriptif yang didukung analisis kualitatif yang diperoleh dari wawancara mendalam, observasi lapangan dan FGD.

Telaah atas RPJMN, RPJM Provinsi Riau dan RPJM Kabupaten Rokan Hulu dan Kampar serta rencana strategis Dinas Kesehatan untuk menganalisis keselarasan perencanaan. Laporan Kinerja Instansi Pemerintah dimanfaatkan untuk mengevaluasi program dan kegiatan intervensi yang telah diimplementasikan.

\section{HASIL DAN PEMBAHASAN}

Kebijakan PenangananStunting di Kabupaten

Pemerintah secara terstruktur mulai dari pemerintah pusat dan daerah telah melakukan berbagai upaya intervensi terhadap stunting. Kementerian Kesehatan sebagai instansi utama dalam penanganan stunting di tingkat pusat telah melakukan berbagai upaya salah satunya membentuk tim untuk Verifikasi Data Situasi Stunting di 10 kabupaten/kota, 100 desa lokus stunting yang ada di Indonesia. Tim verifikasi ini bertujuan untuk melakukan verifikasi data stunting di daerah. Awal tahun 2018, Kementerian Kesehatan bersamainstansi di daerah seperti Dinas Kesehatan Provinsi dan Dinas Kesehatan Kabupaten Rokan Hulu melakukan verifikasi data situasi stunting di Kabupaten Rokan Hulu.

Pelaksanaan verifikasi data situasi stunting Kabupaten Rokan Hulu terbagi menjadi 3 kelompok dan mengunjungi 6 puskesmas dari 10 desa locus, serta mengunjungi masyarakat. Tim yang menggali informasi pada masyarakat yang mempunyai anak stunting melakukan pendalaman informasi mengenai perilaku hidup bersih dan sehat (PHBS), pengetahuan ibu tentang stunting dan penyebab stunting, kelengkapan imunisasi dasar anak balita, sanitasi lingkungan, pemberian tablet tambah darah dan obat cacing pada ibu dan balita, dan lain sebagainya. Sedangkan tim verifikasi data di puskesmas mencari infomasi tentang ketersediaan tenaga promosi kesehatan, gizi, atau pun kesehatan lingkungan, ketersediaan media untuk membantu penyuluhan kepada masyarakat, serta memeriksa ketersediaan logistik obat-obatan. Beberapa hasil yang ditemukan adalah jumlah bayi kategori stunting tidak sebanyak yang ditemukan pada hasil Riskedas 2013.

Hasil inventaris awal data stunting tersebut mengemukakan bahwa salah satu pendekatan keluarga dengan membentuk tim Pembina Desa di setiap Puskesmas. Setiap Puskesmas juga dapat turun ke desa, sehingga pembinaan tidak hanya terletak pada bidan desa tetapi harus ada pembinaan yang berjenjang. Di dalam dokumen perencanaan Kabupaten Rokan Hulu belum memuat stunting sebagai indikator dalam dokumen RPJMD 2016-2021. Pemerintah Rokan Hulu memuat Misi Kedua yaitu "Mewujudkan sumber daya manusia cerdas dan sehat dilandasi keimanan dan ketaqwaan". Seharusnya dalam misi kedua ini menjadi payung terhadap isu stunting. Seiring dengan itu, Renstra Dinas Kesehatan Rokan Hulu hanya memasukkan beberapa indikator pencapaian misi tahun 2018 tanpa ada indikator stunting. Beberapa Indikator kesehatan Pemerintah Rokan Hulu tahun 2018 adalah A: 16/1000 Kelahiran Hidup, AK: 100/100.000 Kelahiran Hidup, Umur Harapan Hidup: 72 Tahun dan Status Gizi: Gizi Buruk < 2 persen.

Pemerintah Rokan Hulu melalui Dinas Kesehatan telah melakukan beberapa program dan kegiatan yang berkaitan dengan intervensi stunting. Target pencapaian kinerja Dinas Kesehatan telah dimuat kedalam perjanjian kinerja dan dilaporkan dalam Laporan Kinerja Instansi Pemerintah (LKjIP). Dinas Kesehatan Kabupaten Rokan Hulu Tahun 2018 memiliki 15 Program. Kabupaten Rokan Hulu dalam Laporan Penanganan Stunting juga telah mengelompokkan beberapa kegiatan intervensi stunting tahun 2018, diantaranya: 1) Penyusunan Regulasi, 2) Penyusunan Rencana Aksi Daerah (RAD), 3) Koordinasi Konvergensi LP/LS, 4) Penguatan Penggerakan Pelaksanaan Intervensi spesifik dan sensitif, 5) Monitoring dan Evaluasi, dan 6) Pencatatan dan Pelaporan

Desa Kepayang Kecamatan Kepenuhan Hulu menjadi satu lokus desa stunting di Kabupaten Rokan Hulu, dimana di desa ini ditemui sebanyak 18 orang anak dengan pertumbuhan anak tergolong lambat, kerdil tidak sesuai dengan usia mereka. Penetapan desa stunting ini didasarkan hasil riset kesehatan dasar (Riskesdas) 2013. 
Di Desa Kepayang, sebagai Kampung $\mathrm{KB}$, telah terbentuk kaderPeran Pembantu Pembina Keluarga Berencana Desa (PPKBD) yang difasilitasi BKKBN. Kader PKKBD sangat berperan di dalam meningkatkan SDM di Desa Kepayang melalui kegiatan-kegiatan yang dilaksanakannya. BKKBNjuga membentuk kelompok Bina Keluarga Balita (BKB) yang mendukung penyiapan generasi emas yang berkualitas, sebagai bagian dari program Kampung KB di Desa Kepayang. PKKBD dan kelompok BKB ini berada dalam satu komplek dengan Posyandu menjadi Posyandu Terpadu. Beberapa faktor yang mendukung terlaksananya suatu program adalah komunikasi yang sudah berjalan dengan baik, sosialisasi dan pusat kesehatan masyarakat dengan melibatkan lintas sektor, sedangkan faktor penghambat termasuk sumber daya infrastruktur masih terbatas (Pujosiswanto, Palutturi, \& Ishak, 2018).

Partisipasi yang memiliki anak di bawah dua tahun (baduta) cukup baik, terutama dalam mengikuti kegiatan yang dilaksanakan di Posyandu Terpadu, di mana letaknya berseberangan dengan Puskesmas Pembantu. Masyarakat secara suka rela dan secara langsung ikut serta dalam kegiatan yang sudah ditetapkan oleh tim kesehatan. Partisipasi orang tua baduta adalah keterlibatan aktif individu maupun kelompok dalam proses yang berdampak pada penurunan prevalensi stunting di Desa Kepayang.

Permasalahan yang muncul di Desa Kepayang (menurut penuturan Kepala Desa) adalah dari 18 anak stunting ada 9 anak yang tidak bisa diintervensi dengan berbagai kegiatan yang dilaksanakan di desa. Tingkat partisipasi ibu Balita dalam mengikuti kegiatan pos pelayanan terpadu (Posyandu) diketahui bahwabagi merekakeluarga pekerja kebun kelapa sawit, nihil. Pembangunan kesehatan di daerah terpencil seringkali mengalami hambatan karena kondisi geografis, kurangnya sarana transportasi, komunikasi serta adanya ketergantungan pada musim menjadikan biaya pembangunan kesehatan menjadi sangat mahal (Luti, Hasanbasri, \& Lazuardi, 2012).

Orang tua anak-anak stunting tersebut bekerja sebagai buruh perkebunan sawit sehingga tidak terpapar informasi dan pelayanan kesehatan yang baik. Pihak desa kesulitan untuk mengintervensi mereka lantaran ketiadaan kartu identitas. Pernah dicoba untuk berkomunikasi dengan pihak dengan perusahaan kelapa sawit untuk mengatasi hal ini, namun pihak perusahaan hanya menyediakan tempat penitipan anak tanpa melakukan invervensi gizi kepada mereka.

Para baduta yang mengalami stunting disebabkan oleh pekerjaan orang tua mereka sebagai buruh tidak tetap terutama pendatang dari Nias. Mereka tidak mendapatkan pelayanan kesehatan yang baik yang telah disediakan Desa Kepayang. Pelaksanaan Posyandu Terpadu, termasukpenimbangan dan pemberian gizitambahan, dilaksanakan pada hari kerja. Sedangkan kedua orang tua baduta tersebut masih bekerja, dan cuti hanya di hari Minggu. Sehingga tidak selaras waktu libur dan waktu pelaksanaan posyandu.

Kesenjangan dalam pemanfaatan pusat kesehatan juga ditemukan dalam kategori lain, yaitu status pekerjaan, tingkat sosial ekonomi, waktu perjalanan dan biaya transportasi ke pusat kesehatan (Laksono, Wulandari, \& Soedirham, 2019). Hasil observasi di Desa Kepayang, waktu dan biaya ke pusat kesehatan menjadi dilema bagi orang tua yang memiliki baduta menjadi buruh tidak tetap, di mana mereka tidak terdaftar menjadi karyawan tetap perusahaan tersebut, tapi tetap bisa bekerja sehingga hak-haknya pun menjadi tidak jelas. Pihak desa sulit untuk memperjuangkan hak-haknyaatau mengintervensi perusahaan karena mereka tidak memiliki kartu indentitas seperti KTP. Akibatnya prevalensi stunting di Desa Kepayang masih tinggi. Desa sulit memberikan intervensi pada baduta terkait orang tua mereka yang tidak memiliki kartu identitas.

Keadaan yang demikian berdampak pada baduta di desa yang tidak terlindungi dengan lingkungan dan kesehatan yang baik. Pihak desa berupaya berdialog dengan manajamen perusahaan perkebunan terkait untuk dapat menyelesaikan kasus tersebut terutama mencegah baduta mereka menjadi stunting. Perlu peran Dinas Ketenagakerjaan Kabupaten Rokan Hulu untuk dapat membantu menyelesaikan masalah izin buruh perkebunan sawit untuk membawa anak baduta mereka ke posyandu padahari penimbangan 
dan pemberian gizi tambahan. Tenaga kesehatan yang ada juga perlu meningkatkan kemampuan analisis permasalahan kesehatan, merumuskan dan melakukan advokasi program dan kebijakan kesehatan dalam rangka pengembangan dan pengelolaan sumber daya manusia kesehatan (Putri, 2017).

Penyebab permasalahan yang mendorong perlunya program penanganan stunting, antara lain masih rendahnya pemahaman ibu terhadap stunting. Hal ini ditemukan di beberapa lokasi seperti Desa Teluk Aur Kecamatan Rambah Samo Kabupaten Rokan Hulu. Ada 3 (tiga) kajian yang melihat hubungan antara pendidikan ayah dan ibu dan anak stunting tetapi tidak menentukan hubungan mana yang lebih kuat ( (Sari, et al., 2010), (Semba, et al., 2011), (Semba, et al., 2007)). Terdapat hubungan antara pendidikan ayah dan anak stunting tetapi hubungan yang lebih kuat antara pendidikan ibu dan anak stunting (Best, et al., 2008) dan (Rachmi, Agho, Li, \& Baur, 2016).

Pemerintah desa telah mengupayakan membuat intervensi terpadu dengan cara membangun PAUD, Posyandu dan Pustu yang berdekatan dalam satu pekarangan. Tujuannya agar mudah diakses, mempersingkat waktu dan menghemat biaya. Harapannnya adalah ketika seorang ibu mengantar anaknya sekolah PAUD maka bisa dalam waktu bersamaan melakukan kunjungan posyandu dan akses pustu untuk mendapatkan makanan tambahan bergizi. Ada studi yang menunjukkan bahwa kejadian stunting dipengaruhi oleh asupan energi, asupan protein, pendapatan keluarga. Asupan protein dipengaruhi oleh pendidikan ibu, status pekerjaan ibu, dan pendapatan keluarga (Utami, Indarto, \& Dewi, 2017).

Kabupaten Kamparbelum memuat stunting sebagai indikator dalam dokumen RPJMD tetapi telah dimuat dalam Misi Pertama yaitu "Menyiapkan SDM yang Handal dan Profesional". Misi ini menjadi payung terhadap isu kualitas dan akses pelayanan kesehatan khususnya stunting dengan sasaran meningkatnya derajat kesehatan masyarakat. Namun indikator tersebut belum menjelaskan secara eksplisit stunting sebagai indikator pembangunan daerah.
Pemerintah Kampar melalui dokumen Perencanaan Strategis (renstra) Dinas Kesehatan Kampar telah memasukkan beberapa Indikator pencapaian yang seharusnya dapat menjadi payung terhadap kegiatan penanganan stunting. Pemerintah Daerah bisa melaksanakan belanja sesuai dengan rencana strategis jangka menengah bagi pencapaian indikator kinerja yang telah ditetapkan (Fanggidae \& Manafe, 2019). Namun Pemerintah Kabupaten Kampar belum memasukkan stunting sebagai indikator capaian kinerja kesehatan. Indikator pencapaian Renstra Dinas Kesehatan Kabupaten Kampar tahun 2018, diantaranya yaitu persentase Puskesmas yang terakreditasi (persen) yaitu 27,26 persen, Peningkatan Tipe Rumah Sakit Daerah yaitu C, Rasio tenaga kesehatan per kecamatan yaitu 13 persen, Angka Harapan Hidup (tahun) yaitu 69,6 , Persentase penduduk dengan jaminan kesehatan (persen) yaitu 82 persen.

Walaupun belum dicantumkan dalam indikator capaian kinerja Dinas Kesehatan Kabupaten Kampar, Dinas Kesehatan telah melakukan beberapa program dan kegiatan yang berkaitan dengan intervensi stunting. Target pencapaian kinerja Dinas Kesehatan telah dimuat dalam perjanjian kinerja dan dilaporkan dalam Laporan Kinerja Instansi Pemerintah (LKjIP) Pemerintah Kabupaten Kampar. Dinas Kesehatan Kabupaten Kampar Tahun 2018 memiliki 21 Program terkait intervensi stunting. Berdasarkan data entry ePPGBM tanggal 18 Juni 2019, dari 28.711 balita yang ditimbang, tinggi badan/ usia maka ditemukan 6.581 balita masuk kategori Stunting (sangat pendek/ pendek) atau setara 22,92 persen.

Keadaan di salah satu lokus stunting di Kabupaten Kampar tidak menunjukkan adanya gambaran umumberkenaan dengan desa stunting seperti yang ditemui di Kabupaten Rokan Hulu. Desa Ranah Singkuang Kecamatan Kampar Kabupaten Kampar masuk sebagai desa stunting. Dari dialog dengan warga dan aparat desa, tidak lagi ditemui baduta yang terindikasi/prevalensi stunting. Beberapa tahun lalu, memang ditemui adanya balita dengan kondisi gizi buruk.

Sebelum ditetapkan sebagai lokus penanggulangan stunting, desa ini sudah melakukan 
beberapa program berkenaan dengan pencegahan stunting. Salah satunya adalah ceramah atau sosialisasi kepada golongan tua (nenek yang memiliki cucu usia remaja) untuk tidak lagi memaksa cucu mereka berumah tangga pada usia dini. Petugas lapangan KB perlu berupaya memadukan kembali kebijakan kesehatan. Jika tidak, akan muncul kembali perkawinan usia muda (Fatoni, et al., 2015). Saat ini (dua tahun terakhir) di Desa Ranah Singkuang tidak lagi ditemui adanya pernikahan di usia remaja. Apakah ini sebagai suatu keberhasilan usaha sosialisasi yang dilakukan PLKB atau karena semakin tingginya partisipasi sekolah usai SLTA? Belum bisa dipastikan karena belum ada riset yang spesifik.

Observasi di Desa Ranah Singkuang terlihat fasilitas kesehatan yang ada cukup baik untuk ukuran sebuah desa. Desa memiliki mobil ambulan sendiri yang dibeli dari APBDesa. Alokasi untuk pembangunan kesehatan merupakan peningkatan kapasitas sektor kesehatan dalam memanfaatkan peluang anggaran desa (Suarsih, et al., 2017). Melalui program-program yang dilakukan oleh instansi pusat, provinsi dan kabupaten, desa telah memiliki sumberair bersih sendiri. Melalui program dari Kementerian Pekerjaan Umum, program sanitasi juga sudah sangat baik.

Perbedaan data Riskesda dan kondisi di desa pada awalnya menyebabkan pihak desa merasa malu karena menjadi lokus stunting. Namun dengan banyaknya program yang diturunkan ke desa, mereka memperoleh prioritas dalam pembangunannya. Pihak Puskesmas makin sering menghadiri hari posyandu dan pihak Dinas Kesehatan memberikan gizi tambahan di setiap aksi posyandu di desa.

Berdasarkan hasil FGD dengan berbagai stakeholder di Kabupaten Rokan Hulu dan Kampar dapat diidentifikasi beberapa permasalahan terkait dengan intervensi penangangan stunting di dua kabupaten di Provinsi Riau.

1. Di awal mengimplementasikan intervensi stunting, Pemerintah Kabupaten dalam hal ini Kabupaten Rokan Hulu masih ragu di dalam penetapan lokasinya

2. Masih kurangnya koordinasi penanganan stunting di kabupaten baik koordinasi di tingkat kabupaten antar dinas maupun koordinasi dengan pemerintah Provinsi Riau

3. Penetapan lokus stunting berdasarkan Riskesdas 2013 masih belum tepat, karena ada desa yang tidak lagi menjadi lokus stunting berdasar kondisi terkini

4. Masih lambannya penerapan stunting di tingkat desa karena perhatian kepala desa lebih kepada infrastruktur dibandingkan dengan intervensi stunting

5. Tidak masuknyakegiatan penanganan stunting dalam rencana pembangunan desa sehingga tidak dianggarkan dalam dana desa

\section{Kebijakan Intervensi Stunting Terintegrasi}

PemerintahProvinsiRiaubarumengakomodir penanganan stunting dalam dokumen perencanaan revisi RPJMD Tahun 2019-2024. Mengacu pada Misi 1 yaitu Mewujudkan Sumber Daya yang Beriman, Berkualitas dan Berdaya Saing Global Melalui Pembangunan Manusia Seutuhnya, kemudian dijabarkan dalam Tujuan 1.1: Meningkatkan kualitas SDM yang berdaya saing dan Sasaran 1.1.2: Meningkatnya kualitas pelayanan kesehatan masyarakat dengan Indikator Kinerja (tujuan/impact/ outcome) adalah Prevalensi Stunting (pendek dan sangat pendek) pada anak di bawah lima tahun/balita.

Dalam Evaluasi Pembangunan Nasional 2017 telah menunjukkan beberapa pencapaian yang baik dalam Peningkatan Derajat Kesehatan dan Gizi Masyarakat, salah satu indikator yang digunakan adalah prevalensi stunting yaitu 26,10 persen. Mengingat perlunya dukungan finansial terhadap penanganan stunting maka Pemerintah pusat telah menganggarkan dana transfer khusus melalui Dana Alokasi Khusus (DAK) 2018 dan DAK 2019. Namun dalam DAK 2018 tidak ada sub bidang penanganan stunting dalam DAK Penugasan.

DAK terbagi atas DAK Reguler, DAK Afirmasi dan DAK Penugasan. DAK merupakan dana transfer khusus yang bersumber dari pendapatan APBN yang dialokasikan kepada daerah tertentu dengan tujuan untuk membantu mendanai kegiatan khusus yang merupakan urusan daerah sesuai dengan pembagian urusan dalam UU Nomor 23 Tahun 2014 tentang Peme- 
rintahan Daerah dan sesuai dengan PN yang bersifat specific grant.

DAK Reguler Bidang Kesehatan dan KB tahun 2018 memiliki sub bidang Reguler Sub Bidang Pelayanan Dasar(Kab/Kota), Sub Bidang Pelayanan Rujukan (Kab/Kota), Sub Bidang Pelayanan Rujukan (Provinsi), Sub Bidang Pelayanan Kefarmasian dan Perbekalan Kesehatan (Kab/Kota), Sub Bidang Pelayanan Kefarmasian dan Perbekalan Kesehatan (Provinsi), dan Sub Bidang Keluarga Berencana (Kab/Kota). Sedangkan DAK Penugasan 2018 terdiri dari Penugasan Provinsi dan Penugasan Kab/Kota.

DAK Penugasan 2019 lebih jelas menyebutkan stunting menjadi salah satu bagian dari subbidang yaitu Sub Bidang Penurunan Stunting selain dari Sub Bidang Pengendalian Penyakit, Sub Bidang rujukan, Sub Bidang Bapelkes. DAK tersebut diharapkan mampu menunjang pencapaian target indikator Prevalensi stunting (pendek dan sangat pendek) pada anak bawah dua tahun dari 32,9\% pada tahun 2013 menjadi 28 persen pada akhir RPJMN 2019.

Seiring dengan upaya Pemerintah Pusat, intervensi stunting Provinsi Riau telah dilakukan baik melalui strategi intervensi spesifik maupun sensitif. Intervensi spesifik yang berkaitan langsung pada gizi ibu dan anak dalam 1000 Hari Pertama Kehidupan (HPK). Intervensi spesifik sebagian besar berada pada program dan kegiatan Dinas Kesehatan baik Dinas Kesehatan Provinsi maupun Dinas Kesehatan Kabupaten Rokan Hulu dan Kampar. Sedangkan intervensi sensitif berada pada stakeholder lintas sektor baik di level provinsi maupun kabupaten.

Lintas sektor yang terlibat dalam intervensi stunting Provinsi Riau terdapat 6 OPD, yaitu Dinas kesehatan, Dinas Pekerjaan Umum dan Penataan Ruang, Dinas Tanaman Pangan, Hortikultura Dan Perkebunan, Dinas Kependudukan, Pencatatan Sipil, Dinas Pengendalian Penduduk dan Keluarga Berencana, Badan Perencanaan Pembangunan Daerah Provinsi. Sedangkan intervensi lainnya lebih banyak melibatkan Pemerintah Kabupaten dan Pemerintah Desa. Intervensi stunting lintas sektor memerlukan koordinasi yang baik dan perlu dituangkan dalam komitmen bersama yang ditandatangani bersama antar OPD terkait.
Pada koordinasi di level provinsi sebagai middle management belum ditemukan adanya koordinasi lintas sektor sehingga program dan kegiatan yang ada berjalan masing-masing dengan sasaran yang berbeda. Koordinasi akan lebih menghasilkan hasil yang optimal jika ada kesepakatan bersama misalnya dalam pembangunan rumah sehat layak huni diprioritaskan kepada locus desa stunting maupun kegiatan lainnya. Berhasilnya pembangunan kesehatan daerah atas hasil sinergisitas peran aktor-aktor pembangunan kesehatan, dari pemerintah, masyarakat, tokoh agama, LSM, para asosiasi profesi dan pemerhati bidang kesehatan (Salesman \& Rahmat, 2017).

\section{SIMPULAN}

Kebijakan penanganan stunting di Provinsi Riau masih on the track, namun beberapa permasalahan terkait koordinasi, pendanaan dan partisipasi dari aparat desa menjadi permasalahan yang umum terjadi di dua kabupaten lokus. Pemerintah secara terstruktur mulai dari pemerintah pusat dan daerah telah melakukan berbagai upaya intervensi terhadap stunting. Pemerintah Rokan Hulu melalui Dinas Kesehatan telah melakukan beberapa program dan kegiatan yang berkaitan dengan intervensi stunting. Target pencapaian kinerja Dinas Kesehatan telah dimuat ke dalam perjanjian kinerja dan dilaporkan dalam Laporan Kinerja Instansi Pemerintah (LKjIP).

Pemerintah pusattelah menganggarkan dana transfer khusus melalui Dana Alokasi Khusus (DAK) 2018 dan DAK 2019. Pemerintah Provinsi Riau baru mengakomodir penanganan stunting dalam dokumen perencanaan revisi RPJMD Tahun 2014-2019. Intervensi stunting Provinsi Riau telah dilakukan baik melalui strategi intervensi spesifik maupun sensitif. Intervensi spesifik sebagian besar berada pada program dan kegiatan dinas Kesehatan baik Dinas Kesehatan. Sedangkan intervensi sensitif berada pada stakeholder lintas sektor baik di level provinsi maupun kabupaten. Koordinasi di level Provinsi belum ditemukan adanya koordinasi lintas sektor sehingga program dan kegiatan yang ada berjalan masing-masing dengan sasaran yang berbeda. 


\section{DAFTAR RUJUKAN}

Anwar, F., Khomsan, A., Riyadi, D., \& Mudjajanto, E. S. 2010. High participation in the Posyandu nutrition program improved children nutritional status. Nutrition Research and Practice 4(3), 208 - 214.

Bardosono, S., Sastroamidjojo, S., \& Lukito, W. 2007. Determinants of child malnutrition during the 1999 economic crisis in selected poor areas of Indonesia. Asia Pacific Journal of Clinical Nutrition 16(3), 512 - 526.

Bergeron, G., \& Castleman, T. 2012. Program ResponsestoAcute and Chronic Malnutrition: Divergences and Convergences. Advances in Nutrition 3(2), 242 - 249.

Bhutta, Z., Berkley, J. A., Bandsma, R. J., Kerac, M., Trehan, I., \& Briend, A. 2017. Severe childhood malnutrition. Nature Reviews Disease Primers 3, 17067.

Dunn, W. N. 2017. Public Policy Analysis: An IntegratedApproach. New York: Routledge.

Fanggidae, H. C., \& Manafe, M. W. 2019. Evaluasi anggaran belanja sebagai alat pengendalian kebijakan pembangunan pada Pemerintah Daerah. Jurnal Ekonomi Pembangunan 4(2), 45 - 52.

Fatoni, Z., Astuti, Y., Seftiani, S., Situmorang, A., Widayatun, \& Purwaningsih, S. S. (2015). Implementasi kebijakan kesehatan reproduksi di Indonesia: Sebelum dan sesudah reformasi. Jurnal Kependudukan Indonesia 10(1), 65 - 74.

Hoddinott, J. F., Rosegrant, M. W., \& Torero, M. (2013). Investments to reduce hunger and undernutrition. Challenge Paper on Hunger and malnutrition. Copenhagen: Copenhagen Consensus Center.

Laksono, A. D., Wulandari, R. D., \& Soedirham, O. 2019. Regional disparities of health center utilization in rural Indonesia. Malaysian Journal of Public Health Medicine 19(1), 158 -166.

Leroy, J., \& Frongillo, E. A. 2019. Perspective: What Does Stunting Really Mean? A Critical Review of the Evidence. Advances in Nutrition 10(2), 196 - 204.

Luti, I., Hasanbasri, M., \& Lazuardi, L. 2012. Kebijakan pemerintah daerah dalam meningkatkan sistem rujukan kesehatan daerah kepulauan di Kabupaten Lingga Provinsi Kepulauan Riau. Jurnal Kebijakan Kesehatan Indoensia 1(1), 24 - 35.

Pujosiswanto, K. H., Palutturi, S., \& Ishak, H. 2018. Policy Implementation of Healthy Indonesia Program Through Family Approach (PIS-PK) In Community Health Center of Polewali Mandar Regency. International Journal of ChemTech Research 11(8), 199 - 203.

Putri,A. 2017. Kesiapan Sumber Daya Manusia Kesehatan dalam Menghadapi Masyarakat Ekonomi Asean(MEA). Medicoeticolegal dan Manajemen Rumah Sakit 6(1), 55 $-60$.

Rachmi, C. N., Agho, K. E., Li, M., \& Baur, L. A. 2016. Stunting, underweight and overweight in children aged 2.0-4.9 years in Indonesia: Prevalence trends and associated risk factors. PLOS ONE 11(5), e0154756.

Salesman, F., \& Rahmat, E. G. 2017. Peta jalan pembangunankesehatan Kabupaten Manggarai Barat tahun 2016-2021. Unnes Journal of Public Health 6(4), 266 - 270.

Sari, M., de Pee, S., Bloem, M. W., Sun, K., Thorne-Lyman, A. L., Moench-Pfanner, R., \& Semba, R. D. 2010. Higher household expenditure on animal source and nongrain foods lowers the risk of stunting among children 0-59 months old in Indonesia: Implications of rising food prices. The Journal of Nutrition 140(1), 195S - 200S.

Suarsih, S., Sunjaya, D. K., Setiawati, E. P., Wiwaha, G, Herawati, D. M., \& Rinawan, F. R. 2017. Analisis kebijakan dana desa untuk pembangunan kesehatan di Kabupaten Malinau dengan pendekatan segitiga kebijakan. Jurnal Sistem Kesehatan 2(4), 211 - 217.

Utami, A. D., Indarto, D., \& Dewi, Y. R. 2017. The Effect of Nutrient Intake and Socioeconomic Factor toward Stunting Incidence among Primary School Students in Surakarta. Journal of Epidemiologi and Public Health 2(1), 1 - 10. 